\title{
ANALISIS KUALITAS UDARA DI KAMAR GELAP YANG MENGGUNAKAN PENGOLAHAN FILM SECARA MANUAL DAN OTOMATIS
}

\section{ANALYSIS OF AIR QUALITY IN THE DARK ROOM WITH MANUAL AND AUTOMATIC FILM PROCESSING}

\author{
Ary Kurniawati ${ }^{1)}$, Dartini ${ }^{2)}$, Asri Indah Aryani ${ }^{3)}$ \\ ${ }^{1,2,3,)}$ Health Polytechnics of Semarang-Indonesia \\ e-mail: ary.kurniawati@poltekkes-smg.ac.id
}

\begin{abstract}
Backgroun: Dark room is the room where the film is being processed as the final stage of the radiographic process, beside its function as a place of handling film and film storage. According to the MSDS, chemical liquid used in film processing can affect human health. It's spill can cause irritation and burns on skin and eyes, irritation and injury to the digestive tract, while its mist or dried residue can cause irritation of the respiratory tract. Good dark room air circulation is required.

Methods: The study was observational study with measurement data retrieval techniques in the darkroom of four hospitals. The collected data then compared to the air quality requirement according Kepmenkes RI No.1204/Menkes/SK/X/2004 and No.1405/Menkes/SK/XI/2002.

Result: The results showed that the physical air quality including temperature and humidity in the $1^{\text {st }}, 2^{\text {nd }}, 3^{\text {rd }}$ and $4^{\text {th }}$ darkroom was higher than the standards. The average air flow in the $1^{\text {st }}, 2^{\text {nd }}$ and $3^{\text {rd }}$ darkroom were up to standards, but there was no airflow in the $4^{\text {th }}$ darkroom. Results of ambient air quality measurements in the $1^{\text {st }}, 2^{\text {nd }}, 3^{\text {rd }}$ and $4^{\text {th }}$ including $\mathrm{CO}, \mathrm{NO}_{2}, \mathrm{SO}_{2}$ and T.VOC did not meet the standards, while the presence of $\mathrm{H} 2 \mathrm{~S}$ and $\mathrm{NH} 3$ were not detected.

Conclusion: Total dust levels in the $1^{\text {st }}, 3^{\text {rd }}$ and $4^{\text {th }}$ darkroom did not exceed the maximum concentration in indoor air $\left(<0.15 \mathrm{mg} / \mathrm{m}^{3}\right)$, while the $2^{\text {nd }}$ darkroom exceed the standard $\left(>0,15 \mathrm{mg} / \mathrm{m}^{3}\right)$. Using of air-conditioning and a dehumidifier with periodic maintenance is needed to resolve the discrepancy physical air quality, beside periodic cleaning and indoor air excahnge maintenance to resolve high levels of dust and gas pollutants.
\end{abstract}

Key word: dark rooms, air quality

\section{PENDAHULUAN}

Pengolahan film radiografi adalah sebuah kegiatan yang bertujuan untuk mendapatkan gambaran nyata yang permanen pada film dan dapat dilihat oleh mata pada kondisi umum. Sebuah film yang terkena eksposi belum dapat dilihat hasilnya jika belum diproses. Proses pengolahan film dilakukan dengan teknik manual maupun automatic processing melalui beberapa tahapan yaitu pembangkitan (developing), pencucian (rinshing), penetapan (fixing), pembilasan (washing), dan pengeringan (drying) (Bushong, 2001).

Larutan developer tersusun dari pengembang (developing atau reducing agents), pengawet (Preservatives), akselerator atau aktivator (accelerators atau activators agent), restrainer, regulator, anti kabut (antifoggant atau starter), pengeras (hardener), pelarut (solvent), agen eksekutor (sequestering agent), yang mana semua berpengaruh terhadap film (Papp, 2006). Komponen larutan fixer antara lain fixing agent, asam (acid), stabiliser (preservative), buffer, pengeras (hardener) dan pelarut (solvent).

Menurut Material Safety Data Sheet (MSDS) larutan pengolahan film dapat memberikan dampak bagi kesehatan manusia. Apa bila bahan tersebut mengenai mata dan kulit dapat menyebabkan iritasi dan luka bakar, apabila tertelan dapat menyebabkan iritasi dan cidera pada saluran pencernaan dan bila menghirup kabut atau residu kering dapat menyebabkan iritasi pada saluran pernafasan.
Kamar gelap merupakan ruangan dimana tahap akhir dari proses pembuatan radiograf dilakukan (Septiadi dkk, 2008). Di dalam kamar gelap terjadi proses penanganan film baik pengisian film ke dalam kaset (loading) maupun pegeluaran film dari kaset (unloading) untuk selanjutnya dilakukan pengolahan film. Selain itu, kamar gelap juga berfungsi sebagai tempat penyimpanan film yang belum terekspose, sehingga membutuhkan sirkulasi udara yang baik agar tidak rusak.

Menurut Ball dan Price (1989), luas sebuah kamar gelap kamar gelap idealnya adalah $10 \mathrm{~m}^{2}$ dengan tinggi langit-langit sekitar $2.5 \mathrm{~m}$ sampai $3 \mathrm{~m}$. Kamar gelap harus memiliki ventilasi yang baik. Ventilasi pada kamar gelap sangat penting karena dalam kamar gelap memiliki ukuran kecil serta terdapat cairan pengolahan film yang memiliki aroma yang menyengat sehingga perlu adanya sirkulasi udara yang baik. Kelembaban relatif di kamar gelap sekitar 40-60\%, dan suhu ruangan antara $18^{\circ}$ dan $20^{\circ} \mathrm{C}$.

Udara, sebagai salah satu komponen lingkungan merupakan kebutuhan yang paling utama untuk mempertahankan kehidupan. Metabolisme dalam tubuh makhluk hidup tidak mungkin dapat berlangsung tanpa oksigen yang berasal dari udara. Selain oksigen terdapat zatzat lain yang terkandung di udara, yaitu karbon monoksida, karbon dioksida, formaldehid, jamur, virus, dan sebagainya. Zat-zat tersebut jika masih berada dalam batas-batas tertentu 
masih dapat dinetralisasi, tetapi jika sudah melampaui ambang batas maka proses netralisasi akan terganggu. Peningkatan konsentrasi zat-zat di dalam udara tersebut dapat disebabkan oleh aktivitas manusia.

Udara dapat dikelompokkan menjadi, udara luar ruangan (outdoor air) dan udara dalam ruangan (indoor air). Kualitas udara dalam ruang sangat mempengaruhi kesehatan manusia karena hampir $90 \%$ hidup manusia berada dalam ruangan. Sebanyak 400 sampai 500 juta orang khususnya di negara yang sedang berkembang sedang berhadapan dengan masalah polusi udara dalam ruangan.

Kualitas udara dalam ruangan (indoor air quality) juga merupakan masalah yang perlu mendapat perhatian karena akan berpengaruh terhadap kesehatan manusia. Timbulnya kualitas udara dalam ruangan umumnya disebabkan oleh beberapa hal, yaitu kurangnya ventilasi udara (52\%) adanya sumber kontaminasi di dalam ruangan (16\%) kontaminasi dari luar ruangan $(10 \%)$, mikroba $(5 \%)$, bahan material bangunan $(4 \%)$, lain-lain $(13 \%)$.

Perwujudan kualitas lingkungan yang sehat merupakan bagian pokok di bidang kesehatan. Udara sebagai komponen lingkungan yang penting dalam kehidupan perlu dipelihara dan ditingkatkan kualitasnya sehingga dapat memberikan daya dukungan bagi mahluk hidup untuk hidup secara optimal.

Berdasarkan latar belakang di atas penulis ingin meneliti lebih lanjut tentang kualitas udara fisik dan kualitas udara ambient di kamar gelap yang menggunakan pengolahan film secara manual dan otomatis, serta upaya yang dilakukan untuk mengatasi ketidaksesuaian kualitas udara di kamar gelap.

Manfaat riset ini yaitu memberi masukan pada Rumah Sakit khususnya mengenai kualitas udara di kamar gelap serta dapat digunakan sebagai acuan dalam upaya untuk mengatasi ketidaksesuaian kualitas udara di kamar gelap serta peningkatan pelaksanaan keselamatan dan kesehatan kerja terutama di kamar gelap yang menggunakan pengolahan film secara manual dan otomatis.

\section{METODE}

Jenis penelitian adalah observasional dengan teknik pengambilan data pengukuran.

Lokasi pengambilan data pada riset ini adalah di kamar gelap yang menggunakan pengolahan film secara manual: RSUD Ajibarang, RS Sinar Kasih Purwokerto dan kamar gelap yang menggunakan pengolahan film secara otomatis: RS Wijaya Kusuma Purwokerto, Laboratorium Klinik Prodia Purwokerto.

Metode pengumpulan data dengan melakukan pengukuran dan pengamatan hasil pengukuran kualitas udara di kamar gelap yang menggunakan pengolahan film secara manual dan otomatis. Pengukuran dilakukan terhadap kondisi udara di kamar gelap yang menggunakan pengolahan film secara manual dan otomatis. Data yang terkumpul kemudian disajikan dalam susunan yang baik dan rapi. Kemudian dibandingkan dengan kualitas udara menurut Kepmenkes RI No.1204/MENKES /SK /X /2004 dan No 1405/MENKES /SK /XI /2002.

\section{HASIL}

Berikut ini data mengenai kondisi kamar gelap di beberapa rumah sakit yang meliputi ukuran ruangan kamar gelap, jenis pengolahan film yang digunakan dan tanggal terakhir penggantian larutan pencucian

Tabel 1. Tabel Kondisi Kamar Gelap

\begin{tabular}{|c|c|c|c|c|c|}
\hline No & Keterangan & RS 1 & RS 2 & RS 3 & RS 4 \\
\hline 1 & $\begin{array}{l}\text { Ukuran } \\
\text { Kamar } \\
\text { Gelap } \\
\text { a. Panjang } \\
\text { b. Lebar } \\
\text { c. Tinggi } \\
\text { d. Luas }\end{array}$ & $\begin{array}{l}3 \mathrm{~m} \\
3 \mathrm{~m} \\
3,3 \mathrm{~m} \\
9 \mathrm{~m}^{2}\end{array}$ & $\begin{array}{l}5,1 \mathrm{~m} \\
4 \mathrm{~m} \\
4 \mathrm{~m} \\
20 \mathrm{~m}^{2}\end{array}$ & $\begin{array}{l}1,75 \mathrm{~m} \\
1,5 \mathrm{~m} \\
3,2 \mathrm{~m} \\
2,6 \mathrm{~m}^{2}\end{array}$ & $\begin{array}{l}2,5 \mathrm{~m} \\
1,5 \mathrm{~m} \\
3 \mathrm{~m} \\
3,75 \mathrm{~m}^{2}\end{array}$ \\
\hline 2 & $\begin{array}{l}\text { Jenis } \\
\text { pengolahan } \\
\text { film }\end{array}$ & $\begin{array}{l}\text { Otomati } \\
\mathrm{s} \quad \& \\
\text { manual }\end{array}$ & manual & manual & $\begin{array}{l}\text { otomati } \\
\mathrm{s}\end{array}$ \\
\hline 3 & $\begin{array}{l}\text { Tgl } \\
\text { penggantian } \\
\text { larutan } \\
\text { pengolahan } \\
\text { film } \\
\text { a. Develope } \\
\quad r \\
\text { b. Fixer } \\
\text { c. Air }\end{array}$ & $\begin{array}{l}18 \text { Okt } \\
18 \text { Okt } \\
\text { Setiap } \\
\text { hari } \\
\text { air } \\
\text { mengali } \\
\text { r }\end{array}$ & $\begin{array}{l}3 \text { Okt } \\
7 \text { Okt } \\
\text { Setiap } \\
\text { hari } \\
\text { air } \\
\text { mengali } \\
\text { r }\end{array}$ & $\begin{array}{l}6 \text { Okt } \\
6 \text { Okt } \\
\text { Setiap } \\
\text { hari } \\
\text { air } \\
\text { mengali } \\
\text { r }\end{array}$ & $\begin{array}{l}22 \text { Nop } \\
22 \text { Nop } \\
\text { Setiap } \\
\text { hari } \\
\text { air } \\
\text { mengal } \\
\text { ir }\end{array}$ \\
\hline 4 & Exshousefan & $\begin{array}{l}\text { Ada, } \\
\text { rusak }\end{array}$ & $\begin{array}{l}\text { Ada, } \\
\text { baik }\end{array}$ & $\begin{array}{l}\text { Ada, } \\
\text { rusak }\end{array}$ & $\begin{array}{l}\text { Ada, } \\
\text { baik }\end{array}$ \\
\hline 5 & $\begin{array}{l}\text { Jenis pintu } \\
\text { kamar gelap }\end{array}$ & $\begin{array}{l}\text { Labirin } \\
\text { dan } \\
\text { pintu } \\
\text { geser }\end{array}$ & $\begin{array}{l}\text { Labirin } \\
\text { dan } \\
\text { pintu } \\
\text { berdaun }\end{array}$ & $\begin{array}{l}\text { Pintu } \\
\text { berdaun }\end{array}$ & $\begin{array}{l}\text { Pintu } \\
\text { berdau } \\
\mathrm{n}\end{array}$ \\
\hline 5 & $\begin{array}{l}\text { Rata-rata } \\
\text { jumlah } \\
\text { pasien setiap } \\
\text { hari }\end{array}$ & $\begin{array}{l}16 \\
\text { pasien }\end{array}$ & $\begin{array}{l}26 \\
\text { pasien }\end{array}$ & $\begin{array}{l}8 \\
\text { pasien }\end{array}$ & $\begin{array}{l}8 \\
\text { pasien }\end{array}$ \\
\hline 6 & $\begin{array}{l}\text { Rata } \\
\text { penggunaan } \\
\text { film setiap } \\
\text { hari }\end{array}$ & $\begin{array}{l}20 \\
\text { lembar }\end{array}$ & $\begin{array}{l}30 \\
\text { lembar }\end{array}$ & $\begin{array}{l}10 \\
\text { lembar }\end{array}$ & $\begin{array}{l}10 \\
\text { lembar }\end{array}$ \\
\hline 7 & $\begin{array}{l}\text { Pengambilan } \\
\text { sampel }\end{array}$ & $\begin{array}{l}15 \text { Nop } \\
2014\end{array}$ & $\begin{array}{l}15 \text { Nop } \\
2014\end{array}$ & $\begin{array}{l}15 \text { Nop } \\
2014\end{array}$ & $\begin{array}{l}3 \text { Des } \\
2014\end{array}$ \\
\hline
\end{tabular}

Kamar gelap merupakan ruangan dimana tahap akhir dari proses pembuatan radiograf dilakukan. Kamar gelap pada RS 1 memiliki luas $9 \mathrm{~m}^{2}$, kamar gelap RS 2 dengan luas 20 $\mathrm{m}^{2}$, kamar gelap RS 3 dengan luas 2,6 $\mathrm{m}^{2}$ dan kamar gelap RS 4 dengan luas $3,75 \mathrm{~m}^{2}$. Menurut Ball dan Price (1989) luas sebuah kamar gelap idealnya $10 \mathrm{~m}^{2}$ dengan tinggi langit-langit 2,5 - $3 \mathrm{~m}$. Dari keempat kamar gelap hanya satu kamar gelap yang memiliki luas mendekati $10 \mathrm{~m}^{2}$ yaitu kamar gelap RS 1 . Tinggi langit-langit pada keempat kamar gelap lebih dari 2,5 $\mathrm{m}$.

Pengukuran kualitas udara dilakukan pada kamar gelap di empat rumah sakit menggunakan EPAS, EPAM, 
anemometer dan gas alert. Hasil pengukuran kualitas udara pada masing-masing kamar gelap adalah sebagai berikut.

Tabel 2. Tabel hasil pengukuran kualitas udara fisik

\begin{tabular}{cllcccc}
\hline No & Parameter & $\begin{array}{c}\text { Standar \& } \\
\text { satuan }\end{array}$ & RS 1 & RS 2 & RS 3 & RS 4 \\
\hline 1 & Suhu & $\begin{array}{l}18-20 \\
{ }^{0} \text { C }\end{array}$ & 27 & 27 & 27 & 24 \\
2 & $\begin{array}{l}\text { Kelembaba } \\
\text { n }\end{array}$ & $\begin{array}{l}40 \% \\
\text { n }\end{array}$ & 65 & 68 & 77 & 48 \\
3 & $\begin{array}{l}\text { Aliran } \\
\text { udara }\end{array}$ & $\begin{array}{l}0,15- \\
0,25 \\
\text { m/detik }\end{array}$ & 0,16 & 0,63 & 0,0 & 0,73 \\
& & & & & \\
\hline
\end{tabular}

Hasil pengukuran kualitas udara secara fisik di kamar gelap RS 1 yaitu, suhu udara $27^{\circ} \mathrm{C}$, kelembaban $65 \%$ dan rata-rata kecepatan aliran udara $0,16 \mathrm{~m} /$ detik. Pada kamar gelap RS 2 yaitu, suhu udara $27^{\circ} \mathrm{C}$, kelembaban $68 \%$ dan kecepatan aliran udara 0,63 m/detik. Pada kamar gelap RS 3 yaitu, suhu udara $27^{\circ} \mathrm{C}$, kelembaban $77 \%$ dan kecepatan aliran udara $0,73 \mathrm{~m} /$ detik. Pada kamar gelap RS 4 yaitu, suhu udara $24^{\circ} \mathrm{C}$, kelembaban $48 \%$ dan kecepatan aliran udara 0 $\mathrm{m} /$ detik.

Tabel 3. Tabel hasil pengukuran kualitas udara ambien

\begin{tabular}{|c|c|c|c|c|c|c|}
\hline No & Parameter & $\begin{array}{l}\text { Standar } \\
\text { \& satuan }\end{array}$ & RS 1 & RS 2 & RS 3 & RS 4 \\
\hline 1 & $\begin{array}{l}\text { Karbon } \\
\text { monoksida } \\
(\mathrm{CO})\end{array}$ & $25 \mathrm{ppm}$ & 0 & 0 & 0 & 0 \\
\hline 2 & $\begin{array}{l}\text { Nitrogen } \\
\text { dioksida } \\
\left(\mathrm{NO}_{2}\right)\end{array}$ & $3,0 \mathrm{ppm}$ & 0,044 & 0,084 & 0 & 0,044 \\
\hline 3 & $\begin{array}{l}\text { Sulfur } \\
\text { dioksida } \\
\left(\mathrm{SO}_{2}\right)\end{array}$ & $2 \mathrm{ppm}$ & 0 & 0 & 0 & 0,048 \\
\hline 4 & $\begin{array}{l}\text { Total } \\
\text { senyawa } \\
\text { organik yang } \\
\text { mudah } \\
\text { menguap } \\
\text { (T.VOC) }\end{array}$ & $1 \mathrm{ppm}$ & 0 & 0 & 0 & 0,011 \\
\hline 5 & $\begin{array}{l}\text { Hidrogen } \\
\text { sulfida }\left(\mathrm{H}_{2} \mathrm{~S}\right)\end{array}$ & - ppm & $\begin{array}{c}\text { Tidak } \\
\text { terdet } \\
\text { eksi }\end{array}$ & $\begin{array}{c}\text { Tidak } \\
\text { terdet } \\
\text { eksi }\end{array}$ & $\begin{array}{c}\text { Tidak } \\
\text { terdet } \\
\text { eksi }\end{array}$ & $\begin{array}{c}\text { Tidak } \\
\text { terdet } \\
\text { eksi }\end{array}$ \\
\hline 6 & $\begin{array}{l}\text { Amonia } \\
\left(\mathrm{NH}_{3}\right)\end{array}$ & $25 \mathrm{ppm}$ & 0 & 0 & 0 & 0 \\
\hline 7 & Debu total & $\begin{array}{c}0,15 \\
\mathrm{mg} / \mathrm{m}^{3}\end{array}$ & 0,034 & 0,314 & 0,032 & 0,115 \\
\hline 8 & $\begin{array}{l}\text { Kadar debu } \\
\text { PM 2,5 }\end{array}$ & $\mu \mathrm{g} / \mathrm{m}^{3}$ & 23 & 29 & 15 & 30 \\
\hline 9 & $\begin{array}{l}\text { Kadar debu } \\
\text { PM 10 }\end{array}$ & $\mu \mathrm{g} / \mathrm{m}^{3}$ & 14 & 31 & 29 & 54 \\
\hline
\end{tabular}

\section{DISKUSI}

Kamar gelap harus memiliki ventilasi yang baik. Ventilasi pada kamar gelap sangat penting karena dalam kamar gelap memiliki ukuran kecil serta terdapat cairan pengolahan film yang memiliki aroma yang menyengat sehingga perlu adanya sirkulasi udara yang baik. Semua kamar gelap memiliki exshousefan tetapi hanya 2 rumah sakit yang masih berfungsi. Pintu kamar gelap juga dapat berfungsi sebagai ventilasi udara. Jenis pintu kamar gelap yang digunakan pada rumah sakit 1 adalah labirin dengan tambahan pintu geser di bagian luar. Pada rumah sakit 2 digunakan pintu labirin dengan bagian luar ditambah pintu berdaun. Pada rumah sakit 3 dan 4 kamar gelapnya menggunakan pintu berdaun dan menghadap ruang pemeriksaan.

Pada kamar gelap RS 1, 2 dan 3 suhu udara mencapai $27^{\circ} \mathrm{C}$ dan $\mathrm{RS} 424^{\circ} \mathrm{C}$ lebih tinggi dari suhu udara yang direkomendasikan yaitu antara $18^{\circ}$ dan $20^{\circ} \mathrm{C}$. Hal ini terjadi karena kamar gelap tidak dilengkapi dengan pendingin udara (air conditioner) sehingga suhunya tidak dapat dikendalikan. Pada kamar gelap RS 4 pintu kamar gelap menghadap ruang pemeriksaan yang dilengkapi dengan AC. Pada saat tidak digunakan, pintu kamar gelap dibuka sehingga suhu udara di kamar gelap menjadi lebih rendah. Kelembabaan udara pada RS 1, 2 dan 3 lebih dari standar yang direkomendasikan yaitu $60 \%$, sedangkan kamar gelap RS 4 masih dalam batas yang direkomendasikan.

Standar kecepatan aliran udara di dalam ruangan adalah 0,15 - 0,25 m/detik. Pada RS 1 rata-rata aliran udara sudah memenuhi standar minimal sebesar $0,16 \mathrm{~m} /$ detik. Hal ini karena adanya mesin pengolahan film otomatis yang memiliki fasilitas pengering film sehingga ada aliran udara yang keluar dari mesin pengolahan film otomatis. RS 2 dan 3 memiliki rata-rata aliran udara memenuhi standar, bahkan lebih yaitu sebesar 0,63 m/detik dan 0,73 m/detik. Pada kamar gelap RS 2 dan 3 memiliki exshousefan yang masih berfungsi dengan baik sehingga ada aliran udara yang cukup. Sedangkan pada RS 4 tidak ada aliran udara di kamar gelap. Hal ini disebabkan karena exhousefan dalam kondisi rusak dan letak kamar gelap yang berhadapan dengan ruang operator dan langsung berhubungan dengan ruang pemeriksaan, ventilasi udara hanya berasal dari pintu ruang pemeriksaan.

Keadaan sirkulasi udara kamar gelap yang buruk dapat mengakibatkan kenaikan suhu dan kelembaban, hal itu dapat meningkatkan densitas dan fog pada radiograf. Menurut Ball dan Price (1989) untuk mengatasi masalah tersebut dapat dilakukan dengan memastikan kelembaban relatif kamar gelap sekitar $40-60 \%$, dan suhu ruangan antara $18^{\circ}$ dan $20^{\circ} \mathrm{C}$. Salah satu fungsi kamar gelap adalah sebagai tempat penyimpanan film sehingga suhu dan kelembaban udara di kamar gelap perlu diperhatikan.

Kandungan karbonmonoksida (CO) pada keempat kamar gelap adalah 0 ppm, tidak melebihi konsentrasi maksimal sebesar 25 ppm, sesuai dengan standar dari Kemenkes no. 1405. Kandungan nitrogen dioksida $\left(\mathrm{NO}_{2}\right)$ pada kamar gelap RS 1: 0,044 ppm, RS 2: 0,084 ppm, RS 3: 0 ppm dan RS 4: 0,044 ppm. kandungan $\mathrm{NO}_{2}$ pada keempat kamargelap tidak melebihi konsentrasi maksimal yaitu 3 ppm. Kandungan sulfur dioksida $\left(\mathrm{SO}_{2}\right)$ pada kamar gelap RS 1, 2 dan 3 adalah 0 ppm, pada $\mathrm{RS} 4$ adalah $0,048 \mathrm{ppm}$. nilai $\mathrm{SO}_{2}$ ini tidak melebihi konsentrasi maksimal yaitu 2 ppm. Tidak terdeteksi adanya kandungan Hidrogen sulfida $\left(\mathrm{H}_{2} \mathrm{~S}\right)$ serta tidak ada kandungan Amonia $\left(\mathrm{NH}_{3}\right)$ di kamar gelap RS 1,2, 3 dan 4.

Karbon monoksida di lingkungan dapat terbentuk secara alamiah, tetapi sumber utamanya adalah dari kegiatan manusia. Sumber CO buatan antara lain kendaraan bermotor, terutama yang menggunakan bahan bakar bensin. Sumber CO 
dari dalam ruang (indoor) termasuk dari tungku dapur rumah tangga dan tungku pemanas ruang. Di dalam kamar gelap tidak terdapat aktivitas pembakaran atau mesin-mesin yang dapat menghasilkan gas karbon monoksida.

Nitrogen monoksida terdapat diudara dalam jumlah lebih besar daripada $\mathrm{NO}_{2}$. Pembentukan $\mathrm{NO}$ dan $\mathrm{NO}_{2}$ merupakan reaksi antara nitrogen dan oksigen diudara sehingga membentuk NO, yang bereaksi lebih lanjut dengan lebih banyak oksigen membentuk $\mathrm{NO}_{2}$. Seperti halnya $\mathrm{CO}$, emisi $\mathrm{NO}_{\mathrm{x}}$ dipengaruhi oleh kepadatan penduduk karena sumber utama $\mathrm{NO}_{\mathrm{x}}$ yang diproduksi manusia adalah dari pembakaran dan kebanyakan pembakaran disebabkan oleh kendaraan bermotor, produksi energi dan pembuangan sampah. Sebagian besar emisi $\mathrm{NO}_{\mathrm{x}}$ buatan manusia berasal dari pembakaran arang, minyak, gas, dan bensin.

Sulfur dioksida mempunyai karakteristik bau yang tajam dan tidak mudah terbakar di udara. Sepertiga dari jumlah sulfur yang terdapat di atmosfir merupakan hasil kegiatan manusia dan kebanyakan dalam bentuk $\mathrm{SO}_{2}$. Dua pertiga hasil kegiatan manusia dan kebanyakan dalam bentuk $\mathrm{SO}_{2}$. Dua pertiga bagian lagi berasal dari sumber-sumber alam seperti vulkano dan terdapat dalam bentuk $\mathrm{H}_{2} \mathrm{~S}$ dan oksida. Beberapa penelitian menunjukkan bahwa iritasi tenggorokan terjadi pada kadar $\mathrm{SO}_{2}$ sebesar $5 \mathrm{ppm}$ atau lebih bahkan pada beberapa individu yang sensitif iritasi terjadi pada kadar 1-2 ppm. $\mathrm{SO}_{2}$ dianggap pencemar yang berbahaya bagi kesehatan terutama terhadap orang tua dan penderita yang mengalami penyakit khronis pada sistem pernafasan kadiovaskular. Individu dengan gejala penyakit tersebut sangat sensitif terhadap kontak dengan $\mathrm{SO}_{2}$, meskipun dengan kadar yang relatif rendah.

Kandungan total senyawa organik yang mudah menguap (T.VOC) di kamar gelap RS 1, 2 dan 3 adalah 0 ppm dan RS 4 adalah 0,011 ppm. Nilai tersebut tidak melebihi konsentrasi maksimal sebagai standar kualitas udara. Sumber utama VOC buatan adalah pelarut, terutama cat dan lapisan pelindung. Pelarut yang diperlukan untuk menyebarkan film pelindung atau dekoratif. Pelarut yang tipikal adalah hidrokarbon alifatik, etil asetat, eter glikol, dan aseton . Paparan jangka panjang dari VOC di lingkungan indoor dapat berkontribusi untuk sindrom gedung sakit . Di kantor, VOC hasil dari perabotan baru, penutup dinding, dan peralatan kantor seperti mesin fotokopi. Ventilasi yang baik dan sistem pendingin udara sangat membantu mengurangi emisi VOC di dalam ruangan. Studi juga menunjukkan bahwa relatif leukemia dan limfoma dapat meningkat melalui pemaparan berkepanjangan VOC di dalam ruangan.

Konsentrasi debu total di kamar gelap RS 1, 3 dan 4 tidak melebihi konsentrasi maksimal di dalam udara ruangan, yaitu $<0,15 \mathrm{mg} / \mathrm{m}^{3}$. Sedangkan konsentrasi debu total di kamar gelap RS 2 melebihi konsentrasi maksimal di dalam udara ruangan, yaitu $>0,15 \mathrm{mg} / \mathrm{m}^{3}$. Menurut Kepmenkes RI nomor 1405 tahun 2002, kadar asbes bebas adalah 5 serat $/ \mathrm{ml}$ udara dengan panjang serat $5 \mathrm{u}$ (mikron). Pada penelitian ini tidak dilakukan pengukuran menggunakan partikulat debu dengan ukuran diameter aerodinamik 5 mikron (PM 5) karena keterbatasan alat. Pengukuran dilakukan untuk kadar debu dengan PM 2,5 dan PM 10. Hasil pengukuran kadar debu pada PM 2,5 di kamar gelap RS 1, 2, 3, dan 4 adalah $23 \mu \mathrm{g} / \mathrm{m}^{3}, 29$ $\mu \mathrm{g} / \mathrm{m}^{3}, 15 \mu \mathrm{g} / \mathrm{m}^{3}$ dan $30 \mu \mathrm{g} / \mathrm{m}^{3}$. Kadar debu pada PM 10 di kamar gelap RS $1,2,3$, dan 4 adalah $14 \mu \mathrm{g} / \mathrm{m}^{3}, 31 \mu \mathrm{g} / \mathrm{m}^{3}, 29$ $\mu \mathrm{g} / \mathrm{m}^{3}$ dan $54 \mu \mathrm{g} / \mathrm{m}^{3}$.

Partikulat debu melayang (Suspended Particulate Matter/SPM) merupakan campuran yang sangat rumit dari berbagai senyawa organik dan anorganik yang terbesar di udara dengan diameter yang sangat kecil, mulai dari < 1 mikron sampai dengan maksimal 500 mikron. Partikulat debu tersebut akan berada di udara dalam waktu yang relatif lama dalam keadaan melayang-layang di udara dan masuk kedalam tubuh manusia melalui saluran pernafasan. Secara alamiah partikulat debu dapat dihasilkan dari debu tanah kering yang terbawa oleh angin.

Ukuran partikulat debu yang membahayakan kesehatan umumnya berkisar antara 0,1 mikron sampai dengan 10 mikron. Pada umunya ukuran partikulat debu sekitar 5 mikron merupakan partikulat udara yang dapat langsung masuk kedalam paru-paru dan mengendap di alveoli.

Upaya mengatasi ketidaksesuaian kualitas udara ini adalah upaya yang dilakukan agar suhu dan kelembaban, debu, pertukaran udara dan bahan pencemar di ruang kerja memenuhi persyaratan kesehatan.

Suhu dan kelembaban, agar ruang kerja perkantoran memenuhi persyaratan kesehatan perlu dilakukan upaya-upaya sebagai berikut : Tinggi langit-langit dari lantai minimal 2,5 m. Bila suhu udara $>28^{\circ} \mathrm{C}$ perlu menggunakan alat penata udara seperti Air Conditioner (AC), kipas angin, dll. Bila kelembaban udara ruang kerja $>60 \%$ perlu menggunakan alat dehumidifier.

Pertukaran udara, agar pertukaran udara ruang perkantoran dapat berjalan dengan baik maka perlu dilakukan upaya-upaya sebagai berikut : Untuk ruangan kerja yang tidak ber AC harus memiliki lubang ventilasi minimal $15 \%$ dari luas lantai dengan menerapkan sistem ventilasi silang. Ruang yang menggunakan AC secara periodik harus dimatikan dan diupayakan mendapat pergantian udara secara alamiah dengan cara membuka seluruh pintu dan jendela atau dengan kipas angin. Membersihkan saringan/filter udara AC secara periodik sesuai ketentuan pabrik.

Debu, agar kandungan debu di dalam udara ruang kerja memenuhi persyaratan kesehatan maka perlu dilakukan upaya-upaya sebagai berikut : Kegiatan membersihkan ruang kerja perkantoran dilakukan pada pagi dan sore hari dengan menggunakan kain pel basah atau pompa hampa (vacuum ритр). Pembersihan dinding dilakukan secara periodik 2 kali/tahun dan dicat ulang 1 kali setahun. Sistem ventilasi yang memenuhi syarat. Melengkapi ruangan dengan alat penangkap debu (Electro Precipitator) dan water sprayer pada cerobong. Menggunakan alat pelindung diri seperti masker.

Gas pencemar, agar kandungan gas pencemar dalam udara ruang kerja tidak melebihi konsentrasi maksimum perlu dilakukan tindakan-tindakan sebagai berikut : Pertukaran udara ruang diupayakan dapat berjalan dengan baik. Ruang kerja tidak berhubungan langsung dengan dapur. Dilarang 
merokok didalam ruang kerja. Tidak menggunakan bahan bangunan yang mengeluarkan bau yang menyengat. Memelihara sistem ventilasi agar berfungsi dengan baik. Menggunakan alat pelindung diri seperti masker gas.

\section{SIMPULAN}

Kualitas udara (fisik) di kamar gelap meliputi suhu udara di kamar gelap RS 1,2 dan 3 adalah $27^{\circ} \mathrm{C}$, RS $424^{\circ} \mathrm{C}$, lebih tinggi dari standar. Kelembaban udara di kamar gelap RS 1,2 dan 3 adalah $65 \%, 68 \%, 77 \%>60 \%$ dan RS 4 adalah $48 \%<$ $60 \%$. Rata-rata aliran udara di dalam kamar gelap RS 1 adalah $0,16 \mathrm{~m} /$ detik sesuai standar, RS 2 dan 3 adalah 0,63 $\mathrm{m} /$ detik dan $0,73 \mathrm{~m} /$ detik $>$ standar serta $\mathrm{RS} 4$ tidak ada aliran udara.

Hasil pengukuran kualitas udara (ambien) di kamar gelap RS 1, 2, 3 dan 4 yang meliputi karbon monoksida, nitrogen dioksida, sulfur dioksida dan T.VOC tidak melebihi standar. Tidak terdeteksi adanya kandungan Hidrogen sulfida $\left(\mathrm{H}_{2} \mathrm{~S}\right)$ serta tidak ada kandungan Amonia $\left(\mathrm{NH}_{3}\right)$ di kamar gelap $\mathrm{RS}$ 1,2, 3 dan 4. Konsentrasi debu total di kamar gelap RS 1, 3 dan 4 tidak melebihi konsentrasi maksimal di dalam udara ruangan, yaitu $<0,15 \mathrm{mg} / \mathrm{m}^{3}$, sedangkan $\mathrm{RS} 2$ melebihi standar, yaitu $>0,15 \mathrm{mg} / \mathrm{m}^{3}$. Kadar debu pada PM 2,5 di kamar gelap RS 1, 2, 3, dan 4 adalah $23 \mu \mathrm{g} / \mathrm{m}^{3}, 29 \mu \mathrm{g} / \mathrm{m}^{3}, 15$ $\mu \mathrm{g} / \mathrm{m}^{3}$ dan $30 \mu \mathrm{g} / \mathrm{m}^{3}$. Kadar debu pada PM 10 di kamar gelap RS $1,2,3$, dan 4 adalah $14 \mu \mathrm{g} / \mathrm{m}^{3}, 31 \mu \mathrm{g} / \mathrm{m}^{3}, 29 \mu \mathrm{g} / \mathrm{m}^{3}$ dan 54 $\mu \mathrm{g} / \mathrm{m}^{3}$.

Upaya mengatasi ketidak sesuaian kualitas udara fisik dengan menggunakan alat penata udara dan dehumidifier serta merawatnya secara periodik. Upaya mengatasi kadar debu yang tinggi dengan membersihkan ruangan dengan lap basah atau pompa hampa secara periodik. Upaya mengatasi adanya gas pencemar dengan adanya pertukaran udara ruang yang baik.

\section{DAFTAR PUSTAKA}

Ball, John, dan Tony Price. 1989. Chesneys' Radiographic Imaging Fifth Edition. Blackwell Scientific Publication : London.

Bontrager, K.L, dan J.P. Lampignano. 2010. Textbook of Radiographic Positioning and Related Anatomy Seventh Edition. Mosby Elsevier : St. Louis.

Bushong, S.C. 2001. Radiologic Science for Technologist Physic, Biology and Protection Seventh Edition. Mosby Inc : USA.

Carroll, Q.B. 1985. Uchs's Principles of Radiographic Exposure, Processing and Quality Control Third Edition. Charles C Thomas Publisher USA.

Chesney, D.N, dan M.O. Chesney. 1981. Radiographic Imaging Fourth Edition. Blackwell Scientific Publications : London.

Frank, E.D, B.W. Long, dan B.J. Smith. 2012. Merrill's Atlas of Radiographic Positioning and Procedures Twelfth Edition Vol. 1. Mosby Elsevier : USA.

Gunn, Chris. 2002. Radiographic Imaging A Practical Approach Third Edition. Churchil Livingston : London.

Jeffrey, Papp. 2006. Quality Management in The Imaging Science. Mosby Inc : USA.

Jenkins, David. 1980. Radiographic Photography and Imaging Prosesses. Kluwer Academic Publishers : London.

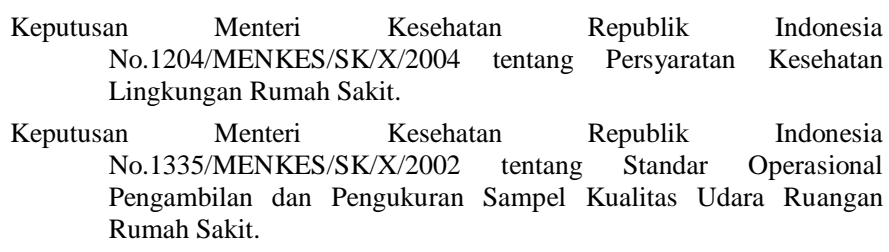

Keputusan Menteri Kesehatan Republik Indonesia No.1335/MENKES/SK/X/2002 tentang Standar Operasional Pengambilan dan Pengukuran Sampel Kualitas Udara Ruangan Rumah Sakit.

Keputusan menteri Kesehatan Republik Indonesia Nomor 1405/MENKES/SK/XI/2002 tentang Persyaratan Kesehatan Lingkungan Kerja Perkantoran dan Industri.

Lloyd, P.J. 2001. Quality Assurance Workbook for Radiographers and Radiological Technologists. Interprint Limited : Malta.

Rahman, Nova. 2009. Radiofotografi. Padang : Penerbit Universitas Baiturrahmah.

Rasad, Sjahriar. 2009. Radiologi Diagnostik. Jakarta: Balai Pustaka.

Widagdo, Suharyo. 2009. Kualitas Udara Dalam Ruang Kerja. Pusat Teknologi dan Keselamatan Nuklir-BATAN : Jakarta. 